-Full Paper-

\title{
The Blastocyst Production Rate and Incidence of Chromosomal Abnormalities by Developmental Stage in In Vitro Produced Porcine Embryos
}

\author{
Carlos Manuel ULLOA ULLOA ${ }^{1,2)}$, Midori YOSHIZAWA ${ }^{1,2)}$, Eiji KOMORIYA ${ }^{2)}$, \\ Akinori MITSUI ${ }^{1,2)}$, Takashi NAGAI ${ }^{3)}$ and Kazuhiro KIKUCHI ${ }^{4)}$
}

\begin{abstract}
1) United Graduate School of Agriculture, Tokyo University of Agriculture and Technology, Tokyo 183-8059, ${ }^{2)}$ Faculty of Agriculture, Utsunomiya University, Utsunomiya 321-8505, ${ }^{3)}$ National Institute of Livestock and Grassland Science, Tsukuba 305-0901 and ${ }^{4)}$ Genetic Diversity Department, National Institute of Agrobiological Sciences, Tsukuba 305-8602, Japan
\end{abstract}

\begin{abstract}
The present study was conducted to determine the relationship between embryonic development speed at different stages (the cleaved stage at $52 \mathrm{~h}$ and the blastocyst stage at 6 days post insemination) and incidences of chromosome abnormalities in in vitro produced porcine embryos. Porcine oocytes were collected from 3-6-mm ovarian follicles obtained at a slaughterhouse and matured in modified NCSU-37 medium for $44-46 \mathrm{~h}$. Following in vitro fertilization with a final concentration of $1 \times 10^{5} \mathrm{sperm} / \mathrm{ml}$ for $3 \mathrm{~h}$, all oocytes were cultured in vitro for $52 \mathrm{~h}$. Day-2 (52 $\mathrm{h}$ after insemination) embryos were classified according to their cleaved stages into 2-cell, 3- to 4-cell, 5- to 8-cell, and >8cell stages; these were cultured separately for additional 4 days (Day 6). The resultant Day-6 blastocysts were classified according to the morphological diameter into 3 grades: Grade A, expanded blastocysts; Grade B, expanding blastocysts; and Grade C, early blastocysts. They were then analyzed chromosomally. The 3- to 4-cell and 5- to 8-cell embryos had significantly high blastocyst development rates (46.1 and 36.9\%, respectively), and these blastocysts contained significantly more cells (40.2 and 42.4 cells, respectively) than those derived from 2-cell embryos and $>8$-cell embryos (28.6 and 26.5 cells, respectively). The incidence of chromosomal abnormalities was significantly higher in the blastocysts derived from 2-cell and >8-cell stage embryos than in the blastocysts derived from the other stage embryos. Furthermore, the grade A blastocysts had the lowest incidence of chromosomal abnormalities (35.3\%) and contained the most cells (48.7 cells). Porcine in vitro production (IVP) yielded a high blastocyst rate and an excellent embryo quality when 3- to 4-cell and 5- to 8-cell stage embryos were selected on Day 2 after insemination. The same criteria yielded a higher quality of expanded blastocysts based on the stage of embryo development and morphology.
\end{abstract}

Key words: Blastocyst, Chromosomal abnormality, Embryo, In vitro production (IVP), Pig

(J. Reprod. Dev. 54: 22-29, 2008)

$\mathrm{n}$ mammals, the technology of in vitro production (IVP) of embryos, which involves in vitro maturation and fertilization of oocytes and in vitro culture of the resultant embryos, has become important for increasing the number of offspring from selected high-quality animals and for reducing the generation intervals for breed improvement in livestock [1, 2]. Moreover, IVP technology has been used in the production of cloned and transgenic animals, which can be used in biomedical research [3-5]. In swine, although embryos have been successfully produced using the IVP system, the development rates to the blastocyst stage and to full term after embryo transfer are still low [6-8]. The viability of porcine embryos produced by IVP is low compared with that of in vivo-derived porcine embryos. For example, porcine embryos produced by IVP are of poor quality in terms of the number of cells compared with those produced in vivo [9].

Although there are undoubtedly multiple causes for the developmental failure that occurs in embryos produced by IVP, chromosomal abnormalities appear to be a major cause of early

Accepted for publication: October 5, 2007

Published online: November 19, 2007

Correspondence: M. Yoshizawa (e-mail: midoriy@cc.utsunomiya-u.ac.jp) embryonic mortality $[10,11]$. Embryos produced by IVP have a high incidence of chromosomal abnormalities, including mixoploidy and polyploidy; these have been linked to a high frequency of polyspermic fertilization [12-14]. Cytogenetic analysis of porcine blastocysts produced in vitro has revealed that about $40 \%$ of the blastocysts are abnormal [15]; this is higher than the $7.3 \%$ reported for in vivo-derived embryos [16]. In cattle, the incidence of mixoploidy is about three times higher in embryos produced by IVP than in those produced in vivo [17]. Embryos with chromosomal abnormalities may result in reproductive failure that is manifested by embryonic developmental arrest or early embryonic death. In humans, cytogenetic studies have shown that the high incidence of chromosomal abnormalities in embryos produced by IVP is responsible for high rates of embryonic death [18] and abortion [10, 11].

To select the best quality embryos for transfer, embryo competence to develop to parturition must be carefully evaluated from the early stages. Quality assessment of preimplantation embryos based on morphological criteria has been used in some species, such as cattle $[19,20]$ and humans $[21,22]$. It appears that the timing of cleavage after insemination is linked to blastocyst formation. Bovine embryos produced by IVP that cleave faster to the 2-cell 
stage after insemination display significantly higher blastocyst rates than embryos that cleaved more slowly [23-25]. Furthermore, it has been reported that the number of blastomeres of embryos at any given time linked to embryo viability and chromosome abnormalities. In the hamster [26], the development potential to the blastocyst stage of embryos that reach the 8-cell stage within a normal time frame is significantly greater than that of $<4$-cell, 4 cell and 5- to 7-cell stage embryos. Moreover, the morulae/blastocysts derived from the 8-cell embryos have better competency to develop to term after embryo transfer. In comparison of human Day-3 IVF embryos with moderately cleaving ones, both slow- and fast-cleaving embryos have low blastocyst formation rates [27] and high incidences of chromosome abnormalities [28].

Despite the relative abundance of cytogenetic data with respect to embryos produced by IVP in other species, few cytogenetic studies of porcine embryos produced by IVP are available. Furthermore, no work has been done to determine the chromosomal quality of porcine embryos based on their early cleaved stages and embryo development stages. In polytocous animals such as swine, although the strategy for efficient embryo transfer is more complicated than that in monotocous animals such as cattle and humans, it is important to eliminate porcine embryos produced by IVP that carry chromosomal abnormalities and to select excellent quality embryos for embryo transfer. Furthermore, determination of the relationship between embryonic development and the incidences of chromosome abnormalities in porcine embryos produced by IVP is required. The present study was conducted to evaluate early cleaved porcine embryos for their developmental competence to the blastocyst stage and for their incidence of chromosome abnormalities.

\section{Materials and Methods}

\section{Oocyte collection and in vitro maturation (IVM)}

Porcine ovaries were obtained from prepubertal gilts at the Utsunomiya Slaughterhouse (Tochigi Prefecture, Japan) and then transported in a sterile saline solution of $0.85 \%(\mathrm{w} / \mathrm{v}) \mathrm{NaCl}$ at $35-$ $37 \mathrm{C}$ to our laboratory within 1 or $2 \mathrm{~h}$. Cumulus-oocyte complexes (COCs) were collected from 3-6-mm-diameter follicles in phosphate buffer solution (PBS) supplemented with $3 \mathrm{mg} / \mathrm{ml}$ of bovine serum albumin, $100 \mathrm{IU} / \mathrm{ml}$ penicillin and $0.1 \mathrm{mg} / \mathrm{ml}$ streptomycin. Only COCs that had a uniform cytoplasm and were surrounded by compact cumulus cells were selected for in vitro maturation. The selected COCs were cultured for 20-22 h in modified North Caroline State University (NCSU)-37 medium as describe by Kikuchi et al. [8]; the medium contained $10 \%(\mathrm{v} / \mathrm{v})$ porcine follicular fluid (pFF), $0.6 \mathrm{mM}$ cysteine, $1 \mathrm{mM}$ dibutyril cAMP (dbcAMP; SigmaAldrich Chemicals, St. Luis, MO, USA), $10 \mathrm{IU} / \mathrm{ml}$ equine chorionic gonadotropin (eCG), $10 \mathrm{IU} / \mathrm{ml}$ human chorionic gonadotropin (hCG), $0.1 \mathrm{mM}$ 2-mercaptoethanol (2-ME) and antibiotics. They were subsequently cultured in the same modified NCSU-37 medium without dbcAMP and hormonal supplements for $24 \mathrm{~h}$. The maturation culture was carried out under $5 \% \mathrm{O}_{2}, 5 \% \mathrm{CO}_{2}$ and $90 \% \mathrm{~N}_{2}$ at $39 \mathrm{C}$. The $\mathrm{pFF}$ was collected in advance by aspirating the fluid of 3-6 mm follicles with a syringe, and it was then centrifuged at 3,000 rpm for $1 \mathrm{~h}$; the supernatant was stored at $-20 \mathrm{C}$ until use.

\section{In vitro fertilization (IVF) of porcine oocytes and in vitro culture (IVC) of the zygotes}

IVF and IVC were conducted according to the previous report of Kikuchi et al. [8]. Briefly, the medium used for IVF was a modified Pig-FM [29] consisting of $90 \mathrm{mM} \mathrm{NaCl}, 12 \mathrm{mM} \mathrm{KCl}, 25 \mathrm{mM}$ $\mathrm{NaHCO}_{3}, 0.5 \mathrm{mM} \mathrm{NaH}_{2} \mathrm{PO}_{4}, 0.5 \mathrm{mM} \mathrm{MgSO}_{4}, 10 \mathrm{mM}$ sodium lactate, $10 \mathrm{mM}$ HEPES, $8 \mathrm{mM} \mathrm{CaCl}_{2}, 2 \mathrm{mM}$ sodium pyruvate, $5 \mathrm{mg} /$ $\mathrm{ml}$ caffeine, $5 \mathrm{mg} / \mathrm{ml}$ bovine serum albumin and antibiotics. Cryopreserved epididymal spermatozoa from Landrace swine [30] were thawed and preincubated for $15 \mathrm{~min}$ at $37 \mathrm{C}$ in medium 199 with Earle's salts and HEPES; the $\mathrm{pH}$ was adjusted to 7.8. A small portion $(10 \mu \mathrm{l})$ of the preincubated spermatozoa was introduced into $90 \mu \mathrm{l}$ IVF droplets containing about 20 COCs surrounded by expanded cumulus cells; they were then co-incubated at $39 \mathrm{C}$ under $5 \% \mathrm{O}_{2}, 5 \% \mathrm{CO}_{2}$ and $90 \% \mathrm{~N}_{2}$ for $3 \mathrm{~h}$. The final sperm concentration was adjusted to $1 \times 10^{5} \mathrm{sperm} / \mathrm{ml}$. The day of insemination was defined as Day 0. After removal of the cumulus cells and the spermatozoa attached to the surface of the zona pellucida by passing the oocytes several times through a narrow glass pipette, all oocytes were transferred into IVC medium. From Days 0 to 2, IVC was performed in IVC-PyrLac medium and, from Days 2 to 6, IVC was performed in IVC-Glu medium [8]. The IVC-PyrLac medium consisted of NCSU-37 [31] without glucose that was supplemented with $0.17 \mathrm{mM}$ sodium pyruvate, $2.73 \mathrm{mM}$ sodium lactate and 50 $\mu \mathrm{M}$ 2-ME. On Day 2 (52 h after insemination), the embryos that were not degenerated and that consisted of approximately equal blastomeres having neither very light nor very dark cytoplasm were determined to be normal. The Day-2 normal embryos were classified under a stereomicroscope based on their cleaved stages into: 2cell, slow cleaved embryos; 3- to 4-cell, moderately slow cleaved embryos; 5- to 8-cell, moderately fast cleaved embryos; and $>8$ cell, fast cleaved embryos. They were then cultured separately to the blastocyst stage in IVC-Glu medium consisting of NCSU-37 supplemented with $4 \mathrm{mg} / \mathrm{ml} \mathrm{BSA}$ and $50 \mu \mathrm{M} 2-\mathrm{ME}$. IVC was carried out at $39 \mathrm{C}$ under $5 \% \mathrm{O}_{2}, 5 \% \mathrm{CO}_{2}$ and $90 \% \mathrm{~N}_{2}$ for 6 days.

\section{Chromosomal analysis}

Day-6 blastocysts in each cell stage group were classified into the following three grades according to stages of embryonic development and morphological diameter: Grade A embryos at the expanded stage, Grade B embryos at the expanding stage and Grade $\mathrm{C}$ embryos at the early blastocyst stage. After grading, we measured the diameters of the individual embryos in each group. The diameters of the embryos were $>$ approximately $180 \mu \mathrm{m}(191.3$ $\pm 9.5)$ in the Grade A embryos, $150-180 \mu \mathrm{m}(166.3 \pm 5.1)$ in the Grade B embryos, and < about $150 \mu \mathrm{m}(140.8 \pm 3.1)$ in the Grade C embryos. The blastocysts were cultured for $17 \mathrm{~h}$ in IVC-Glu medium containing $30 \mathrm{ng} / \mathrm{ml}$ vinblastine sulfate as a mitotic inhibitor. Chromosome preparation was performed in a high humidity room according to the method of Yoshizawa et al. [32]. Briefly, the blastocysts were placed in a $0.4 \mathrm{ml}$ hypotonic solution of $1 \%$ (w/v) sodium citrate for 13-15 min and then fixed mildly by pouring about $0.02 \mathrm{ml}$ acetic alcohol (1 part acetic acid: 1 part methanol) into the hypotonic solution. After few minutes, each 
blastocyst was individually placed onto each clean glass slide, and the blastomeres were separated using a very small droplet of acetic acid. Finally, their chromosomes were spread using several drops of acetic alcohol fixative ( 1 part acetic acid: 3 parts methanol). The chromosome samples were sufficiently air-dried and then stained with $2 \%(w / v)$ Giemsa solution for $10 \mathrm{~min}$.

\section{Cytogenetic criteria}

The total number of cells with nuclei, analyzable metaphases (intact and non-overlapping), and chromosomes were examined under a microscope (Olympus, Tokyo, Japan) with a magnification of $600(40 \times 15)$ or $900(60 \times 15)$. The mitotic index was determined as the ratio of the number of metaphase plates of the total number of cells. Embryos that had two sets of chromosomes $(2 \mathrm{n}=$ 38 ) in all countable metaphases were defined as normal diploids, and those in which all analyzable metaphases (nuclei) contained one set of chromosomes $(n=19)$ were defined as haploids. Embryos containing more than two sets of chromosomes in all countable nuclei were defined as polyploids (3n, $4 n, 5 n$, etc.), and those with a mixture of diploid cells and haploid $(n / 2 n)$, triploid $(2 n / 3 n)$, tetraploid $(2 n / 4 n)$ or other type of polyploid cells were defined as mixoploids.

\section{Statistical analysis}

The chi-square test was used to analyze the differences among the blastocyst rates of the various cell stage embryos and to assess the differences in chromosomal abnormalities among the blastocyst groups. Data for the average number of cells per blastocyst were assessed using the Kruskal-Wallis test and Dunn's multiple comparisons test. A value of $\mathrm{P}<0.05$ was considered statistically significant.

\section{Results}

\section{Blastocyst production and grading}

Of a total of 1,601 oocytes used for IVF, 1,202 (75.1\%) cleaved on Day 2 after insemination, and 1,006 (83.7\%) of the cleaved embryos were found to be normal (Table 1). The Day- 6 total blastocyst rate, which was calculated based on the total number of inseminated oocytes, was $23.1 \%(370 / 1,601)$, while the rate for the cleaved normal embryos was $36.8 \%(370 / 1,006)$.

On Day 2 ( $52 \mathrm{~h}$ after insemination), there were significantly more 3- to 4-cell and 5- to 8-cell embryos than 2-cell and $>8$-cell embryos (Table 2). The 3- to 4-cell and 5- to 8-cell embryos had significantly $(\mathrm{P}<0.05)$ higher blastocyst rates $(46.1$ and $36.9 \%$, respectively) than the 2-cell and $>8$-cell embryos ( 17.5 and $16.8 \%$, respectively). Many of the blastocysts from the 3- to 4-cell and the 5- to 8-cell stage embryos developed into expanded blastocysts (Grade A); their rates of development into expanded blastocysts (52.9 and $51.2 \%$, respectively) were significantly $(\mathrm{P}<0.05)$ higher than those of the 2-cell (15.0\%) and $>8$-cell embryos (17.6\%). On the other hand, many of the blastocysts derived from the 2 - and $>8$ cell stage embryos developed into Grade C blastocysts.

\section{The number of cells and incidences of chromosomal abnormalities in blastocysts derived from various Day-2 cell stage embryos}

A total of 370 Day- 6 porcine blastocysts produced by IVP were prepared for chromosomal analysis, including 20, 206, 127 and 17 blastocysts derived from 2-cell, 3- to 4-cell, 5- to 8-cell and >8-cell embryos, respectively (Table 3). Overall, 62.4\% (231/370) of the blastocysts prepared as chromosome samples were analyzed, including $75.0,67.5,54.3$ and $47.1 \%$ of the 2-cell, 3 - to 4 -cell, 5 - to 8 -cell and $>8$-cell groups, respectively. Overall, the mean number of cells per blastocyst was $39.8 \pm 15.7$. The numbers of cells per blastocyst were similar in the 3- to 4-cell and 5- to 8-cell embryos ( $40.2 \pm 15.4$ and $42.4 \pm 16.8$, respectively) and were significantly $(\mathrm{P}<0.05)$ higher than those of the blastocysts derived from the 2cell and $>8$-cell embryos (28.6 \pm 6.9 and $26.5 \pm 5.8$, respectively). There were no significant differences in the number of metaphases per blastocyst or mitotic index between the blastocysts derived from any of the Day-2 embryo groups.

The overall incidence of chromosomal abnormalities was $45.9 \%$ (Table 4). Notably, chromosomal abnormalities were significantly $(\mathrm{P}<0.05)$ more common in blastocysts derived from 2-cell embryos $(80.0 \%)$ and $>8$-cell embryos $(87.5 \%)$ than in blastocysts derived from 3 - to 4 -cell embryos $(41.0 \%)$ and 5 - to 8 -cell embryos

Table 1. Results of in vitro production of porcine embryos

\begin{tabular}{lc}
\hline No. of oocytes used in IVF & 1,601 \\
No. of embryos cleaved at day $2(\%)$ & $1,202(75.1)$ \\
No. of normal embryos (\%) & $1,006(83.7)$ \\
No. of degenerated embryos (\%) & $196(16.3)$ \\
No. of blastocysts (\%*) & $370(23.1)$ \\
Blastocysts/cleaved embryos & $(370 / 1,006: 36.8)$ \\
\hline
\end{tabular}

*The percentage was calculated based on the total number of inseminated oocytes.

Table 2. Results of development of embryos at various cell stages to the blastocyst stage and grading of the blastocysts

\begin{tabular}{lcccrr}
\hline & \multicolumn{3}{c}{ Embryo cell stages } & Total \\
\cline { 2 - 4 } & 2 cells & 3 to 4 cells & 5 to 8 cells & $>8$ cells & \\
\hline No. of embryos on Day 2 (\%) & $114(11.3)^{\mathrm{a}}$ & $447(44.4)^{\mathrm{b}}$ & $344(34.2)^{\mathrm{b}}$ & $101(10.1)^{\mathrm{a}}$ & 1,006 \\
No. of blastocysts on Day 6 (\%) & $20(17.5)^{\mathrm{a}}$ & $206(46.1)^{\mathrm{b}}$ & $127(36.9)^{\mathrm{b}}$ & $17(16.8)^{\mathrm{a}}$ & $370(36.8)$ \\
Grade A (\%*) & $3(15.0)^{\mathrm{a}}$ & $109(52.9)^{\mathrm{b}}$ & $65(51.2)^{\mathrm{b}}$ & $3(17.6)^{\mathrm{a}}$ & $180(48.6)$ \\
Grade B (\%*) & $8(40.0)$ & $63(30.6)$ & $35(27.6)$ & $4(23.6)$ & $110(29.8)$ \\
Grade C (\%*) & $9(45.0)^{\mathrm{a}}$ & $34(16.5)^{\mathrm{b}}$ & $27(21.2)^{\mathrm{b}}$ & $10(58.8)^{\mathrm{a}}$ & $80(21.6)$ \\
\hline
\end{tabular}

The values with different superscripts $(\mathrm{a}-\mathrm{b})$ in the same row are significantly $(\mathrm{P}<0.05)$ different. *The percentages for Grades $\mathrm{A}, \mathrm{B}$ and $\mathrm{C}$ were calculated from the number of blastocysts on Day 6 for each cell stage group of embryos. 
Table 3. Cell numbers and mitotic indexes of blastocysts derived from embryos at various cell stages

\begin{tabular}{lccccc}
\hline & \multicolumn{4}{c}{ Embryo cell stages } & Total \\
\cline { 2 - 5 } & 2 cells & 3 to 4 cells & 5 to 8 cells & $>8$ cells & \\
\hline No. of prepared blastocysts & 20 & 206 & 127 & 17 & 370 \\
No. of analyzed blastocysts (\%) & $15(75.0)$ & $139(67.5)$ & $69(54.3)$ & $8(47.1)$ & $231(62.4)$ \\
No. of cells per blastocyst* & $28.6 \pm 6.9^{\mathrm{a}}$ & $40.2 \pm 15.4^{\mathrm{b}}$ & $42.4 \pm 16.8^{\mathrm{b}}$ & $26.5 \pm 5.8^{\mathrm{a}}$ & $39.8 \pm 15.7$ \\
No. of metaphases per blastocyst* & $1.6 \pm 0.9$ & $2.6 \pm 1.9$ & $2.5 \pm 1.7$ & $1.5 \pm 0.5$ & $2.6 \pm 2.4$ \\
Mitotic index*** & $5.6 \pm 2.6$ & $6.3 \pm 4.6$ & $5.9 \pm 3.6$ & $5.6 \pm 1.7$ & $6.3 \pm 4.1$ \\
\hline
\end{tabular}

*The data are presented as means $\pm \mathrm{SD}$. The values with different superscripts $(\mathrm{a}-\mathrm{b})$ in the same row are significantly $(\mathrm{P}<0.05)$ different.

**The mitotic index was calculated as the ratio of the number of metaphases for the total number of cells.

Table 4. Incidence of chromosomal abnormalities in blastocysts derived from embryos at various cell stages

\begin{tabular}{|c|c|c|c|c|c|}
\hline & \multicolumn{4}{|c|}{ Embryo cell stages } & \multirow[t]{2}{*}{ Total } \\
\hline & 2 cells & 3 to 4 cells & 5 to 8 cells & $>8$ cells & \\
\hline No. of analyzed blastocysts & 15 & 139 & 69 & 8 & 231 \\
\hline No. of normal blastocysts (\%) & $3(20.0)^{\mathrm{a}}$ & $82(59.0)^{b}$ & $39(56.5)^{\mathrm{b}}$ & $1(12.5)^{\mathrm{a}}$ & $125(54.1)$ \\
\hline No. of abnormal blastocysts (\%) & $12(80.0)^{\mathrm{a}}$ & $57(41.0)^{\mathrm{b}}$ & $30(43.5)^{b}$ & $7(87.5)^{\mathrm{a}}$ & $106(45.9)$ \\
\hline Haploid $(\% *)$ & $2(13.3)$ & $2(0.4)$ & $1 \quad(1.5)$ & $0 \quad(0.0)$ & $5(2.2)$ \\
\hline Polyploid $(\% *)$ & $6(40.0)^{\mathrm{a}}$ & $27(19.4)^{\mathrm{b}}$ & $11(15.9)^{\mathrm{b}}$ & $5(62.5)^{\mathrm{a}}$ & $49(21.2)$ \\
\hline Mixoploid $(\% *)$ & $4(26.7)$ & $28(20.1)$ & $18(26.1)$ & $2(25.0)$ & $52(22.5)$ \\
\hline
\end{tabular}

The values with different superscripts $(a-b)$ in the same row are significantly $(\mathrm{P}<0.05)$ different. ${ }^{*}$ The percentages of chromosome abnormalities; the percentages for haploid, polyploid and mixoploid were calculated from the number of analyzed blastocysts.

Table 5. Cell numbers and mitotic indexes of the blastocysts according to morphological grade

\begin{tabular}{lcccc}
\hline & \multicolumn{3}{c}{ Blastocyst grades } & \multirow{2}{*}{ Total } \\
\cline { 2 - 4 } & Grade A & Grade B & Grade C & \\
\hline No. of prepared blastocysts & 180 & 110 & 80 & 370 \\
No. of analyzed blastocysts (\%) & $136(75.6)^{\mathrm{a}}$ & $60(54.5)^{\mathrm{ab}}$ & $35(43.8)^{\mathrm{b}}$ & $231(62.4)$ \\
No. of cells per blastocyst* & $48.7 \pm 13.5^{\mathrm{a}}$ & $28.0 \pm 4.4^{\mathrm{b}}$ & $19.9 \pm 4.1^{\mathrm{c}}$ & $39.8 \pm 15.7$ \\
No. of metaphases per blastocyst* & $3.5 \pm 2.3$ & $1.9 \pm 1.7$ & $1.2 \pm 0.6$ & $2.6 \pm 2.4$ \\
Mitotic index*** & $7.3 \pm 5.9$ & $6.6 \pm 3.1$ & $5.5 \pm 3.3$ & $6.3 \pm 4.1$ \\
\hline
\end{tabular}

*The data are presented as means \pm SD. The values with different superscripts $(a-c)$ in the same row are significantly $(\mathrm{P}<0.05)$ different. ${ }^{* *}$ The mitotic index was calculated as the ratio of the number of metaphase plates of the total number of cells.

$(43.5 \%)$. On the other hand, the frequency of normal diploidy was significantly $(\mathrm{P}<0.05)$ higher in the blastocysts derived from 3 - to 4-cell embryos $(59.0 \%)$ and 5 - to 8 -cell embryos $(56.5 \%)$ than in the blastocysts derived from 2-cell embryos (20.0\%) and $>8$-cell embryos (12.5\%).

Haploidy, polyploidy and mixoploidy were found in all groups, with the exception that no haploidy was observed in blastocysts derived from $>8$-cell embryos. Of the blastocysts with chromosomal abnormalities, those derived from 2-cell embryos and $>8$ cell embryos had significantly $(\mathrm{P}<0.05)$ higher incidences of polyploidy than the blastocysts derived from 3- to 4-cell and 5- to 8-cell embryos. The blastocysts derived from 2-cell embryos had a high haploidy rate but there was no significant difference compared with the blastocysts derived from the other groups of embryos.
The number of cells and incidences of chromosomal abnormalities in blastocysts based on morphology

A total of 370 blastocysts were statistically analyzed based on grade (Table 5). Almost all the Grade A blastocysts (75.6\%) could be analyzed chromosomally; significantly more Grade A blastocysts could be analyzed chromosomally than Grade $\mathrm{C}$ blastocysts $(43.8 \%, \mathrm{P}<0.05)$. The Grade A blastocysts had significantly $(\mathrm{P}<0.05)$ more cells $(48.7 \pm 13.5)$ than the Grade B $(28.0 \pm 4.4)$ and Grade C $(19.9 \pm 4.1)$ blastocysts. Although the Grade A blastocysts had more metaphases per blastocyst and a high mitotic index, no significant differences were found among the three grades of blastocysts. The Grade A group had a significantly $(\mathrm{P}<0.05)$ lower incidence of chromosomal abnormalities (35.3\%) than the $\mathrm{B}$ $(51.7 \%)$ and $\mathrm{C}(77.1 \%)$ groups (Table 6$)$. Haploidy, polyploidy (triploidy, 3n: Fig. 1; tetraploidy, 4n; and others) and mixoploidy (n/2n, 2n/3n, 2n/4n: Fig. 2; and others) were found in all grades of blastocysts. There were no significant differences in the incidences 
Table 6. Incidence of chromosomal abnormalities in the blastocysts according to morphological grade

\begin{tabular}{lccrr}
\hline & \multicolumn{3}{c}{ Blastocyst grades } & \multirow{2}{*}{ Total } \\
\cline { 2 - 4 } & Grade A & Grade B & Grade C & \\
\hline No. of analyzed blastocysts & 136 & 60 & 35 & 231 \\
No. of normal blastocysts (\%) & $88(64.7)^{\mathrm{a}}$ & $29(48.3)^{\mathrm{b}}$ & $8(22.9)^{\mathrm{c}}$ & $125(54.1)$ \\
No. of abnormal blastocysts (\%) & $48(35.3)^{\mathrm{a}}$ & $31(51.7)^{\mathrm{b}}$ & $27(77.1)^{\mathrm{c}}$ & $106(45.9)$ \\
$\quad$ Haploid (\%*) & $1(0.8)$ & $1(1.7)$ & $3(8.6)$ & $5(2.2)$ \\
$\quad$ Polyploid (\%*) & $18(13.2)^{\mathrm{a}}$ & $16(26.7)^{\mathrm{b}}$ & $15(42.8)^{\mathrm{b}}$ & $49(21.2)$ \\
$\quad$ Mixoploid (\%*) & $29(21.3)$ & $14(23.3)$ & $9(25.7)$ & $52(22.5)$ \\
\hline
\end{tabular}

The values with different superscripts $(\mathrm{a}-\mathrm{c})$ in the same row are significantly $(\mathrm{P}<0.05)$ different. ${ }^{*}$ The percentages of chromosome abnormalities; the percentages for haploid, polyploid and mixoploid were calculated from the analyzed blastocysts.

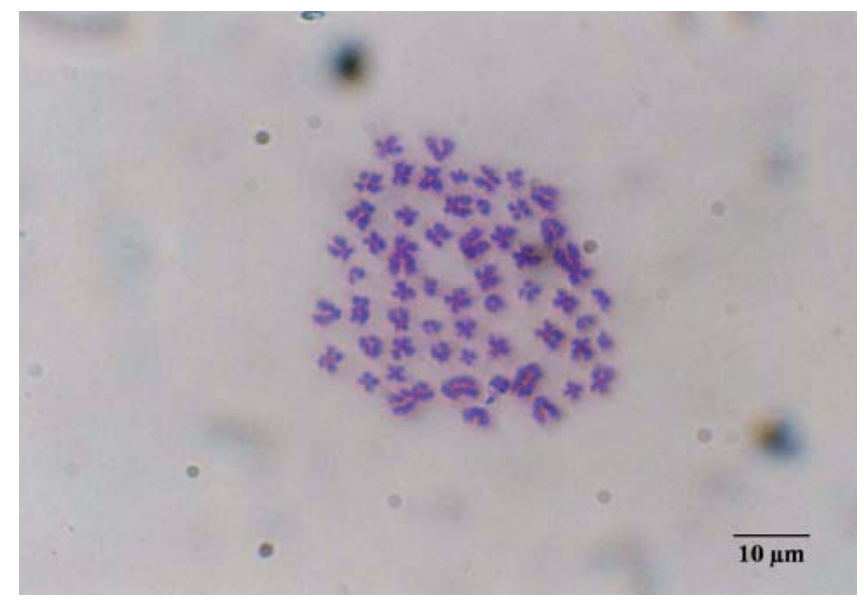

Fig. 1. A microphotograph of a triploid (3n) metaphase seen in an in vitro produced porcine blastocyst. There are 57 chromosomes in this metaphase.

of haploidy and mixoploidy among the three grades. However, the incidence of polyploidy was significantly $(\mathrm{P}<0.05)$ lower in the Grade A, $13.2 \%$, than in the Grades B and C, $26.7 \%$ and $42.8 \%$, respectively.

With respect to the relationship between chromosomal abnormality and the numbers of cells in the blastocysts, it was found that diploid blastocysts had significantly $(\mathrm{P}<0.05)$ more cells than polyploid and haploid blastocysts $(41.4 \pm 13.9,28.2 \pm 10.2$ and $25.8 \pm$ 7.7, respectively; Fig. 3).

\section{Discussion}

In the present study, the overall blastocyst rate $(23.1 \%)$ for all the inseminated oocytes was similar to the rate previously reported by Kikuchi et al. [8] (25.3\%); however, it was slightly lower than the rates reported by Somfai et al. [33] (32\%) and Karja et al. [34] $(31.3 \%)$. When the embryos were classified by their cleaved stages on Day 2, the blastocyst rate of the moderate stage embryos (3- to 4-cell and 5- to 8-cell embryos) was significantly higher than the rates of the delayed or slow (2-cell embryos) and fast stage ( $>8$-cell embryos) embryos. Alikani et al. [27] noted similar results with in vitro-derived human Day-3 embryos; they reported that slow $(<7$

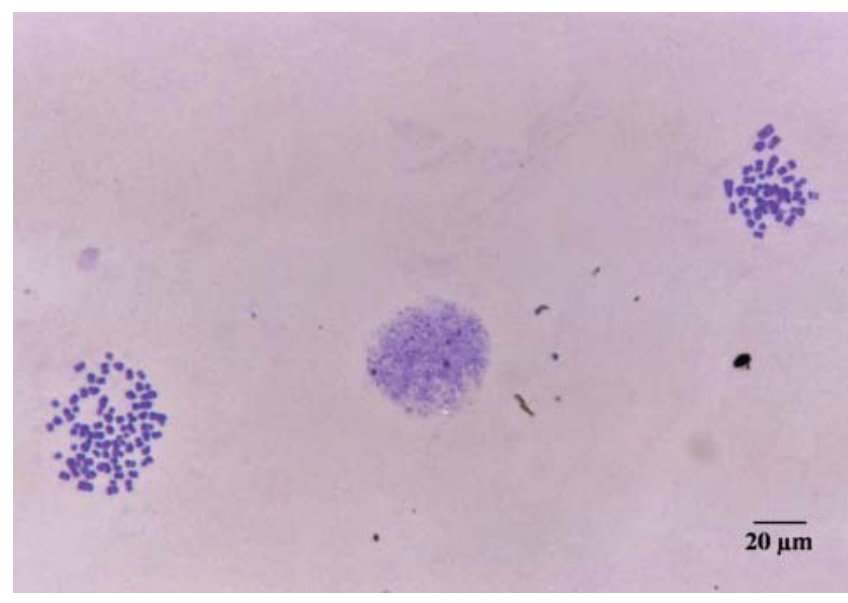

Fig. 2. A microphotograph of mixoploidy $(2 n / 4 n)$ seen in an in vitro produced porcine blastocyst. Diploid (2n: right) and tetraploid $(4 \mathrm{n}$ : left) metaphases can be seen in this image.

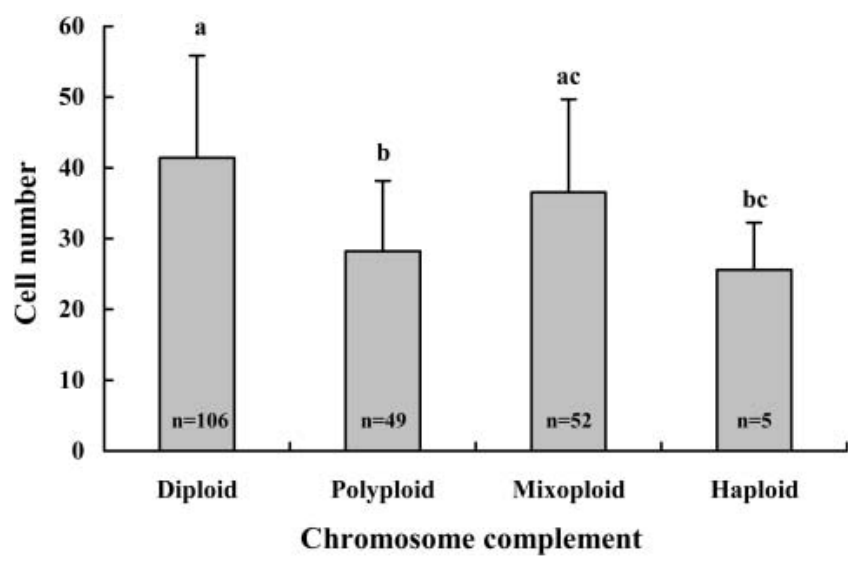

Fig. 3. The cell numbers (means $\pm \mathrm{SD}$ ) of in vitro produced Day-6 porcine blastocysts based on their chromosome complements. Different letters $(a, b, c)$ denote statistically different values $(\mathrm{P}<0.05)$.

cells) and fast ( $>8$ cells) cleavage of embryos had a significantly negative effect on normal blastocyst formation. On the other hand, it has been reported that cattle embryos that divided faster into 2 
cells before $30-31 \mathrm{~h}$ after insemination had a significantly higher proportion of morula-blastocysts by Day 8 than embryos that divided later [23]. McKiernan and Bavister [26] have also reported that hamster embryos $(<4$ cells $)$ with slower cleavage within a time frame were less likely to reach the blastocyst stage than embryos that reached the 8-cell stage within a normal time frame when they were cultured in vitro. Mateusen et al. [35] have shown that porcine embryos with fragmentation exceeding $15 \%$ of the embryo volume have a significantly negative impact on embryonic development. In the present study, the small number of cells present in the Day- 2 embryos with $>8$ cells may reflect a high frequency of fragmentation; this is considered to be a cause of a low blastocyst rate. Furthermore, Day- 2 embryos with $>8$ cells may be products of abnormal cleavage ( 3 or more cells) caused by polyspermy at the first cleavage division [36]. Abnormal cell division was also observed in porcine embryos produced by IVF at the first cleavage division (unpublished our data).

The average number of cells per blastocyst found in the present study was similar to that previously reported by Kikuchi et al. [8], Somfai et al. [33] and Karja et al. [34]. Blastocysts derived from 3to 4-cell embryos and 5- to 8-cell embryos had significantly more cells than those from the other cell stage embryos. This result is not in agreement with our hypothesis that, on Day 2, embryos with $>8$ cells might have more cells at the blastocyst stage than 3- to 4-cell embryos and 5- to 8-cell embryos; this indicates that the development of $>8$-cell embryos slows down after Day 2. The results of the present study, which found that expanded blastocysts had more cells than expanding and early blastocysts, are in agreement with the report of Jakobsen et al. [37], which showed that hatched bovine blastocysts (fast development) had more cells than nonexpanded blastocysts (slow development). In the present study, the expanded blastocysts were evaluated as being of better quality than the other blastocysts based on the general criterion that "the larger the number of cells in embryos the better the quality," as discussed by Jakobsen et al. [37] and Farin et al. [38]. Furthermore, the blastocysts that developed from 3- to 4-cell embryos and 5- to 8-cell embryos were also evaluated as being of high quality because they contained a large number of cells at the blastocyst stage.

The mitotic index, which is the proportion of mitotic metaphases among all nuclei, reflects embryo viability. In the present study, the low mitotic index (6.3) was similar to that reported in Day-6 porcine blastocysts produced by IVP (7.7) by McCauley et al. [15]; this indicates that relatively few cells had undergone mitosis. A mitotic index of $20 \%$ has been reported for bovine blastocysts produced by IVP and treated with vinblastine for $17 \mathrm{~h}$ [33], while a higher mitotic index (92\%) has been reported for mouse morulae derived from natural mating after vinblastine treatment for $10 \mathrm{~h}$ [39]. The low mitotic indices of porcine blastocysts produced by IVP compared with bovine and mouse embryos suggest that cell division occurs more slowly in porcine embryos than in bovine and mouse embryos. Moreover, porcine embryos produced by IVP may be less viable than bovine embryos produced by IVP.

In the present study, the total incidence of chromosomal abnormalities in the Day-6 porcine blastocysts was $45.9 \%$; this was higher than the incidence of $39.1 \%$ reported by McCauley et al. [15]. The chromosomal abnormalities observed in the present study were mainly polyploidy and mixoploidy. During in vitro fertilization in mice [12,13], cattle [14] and swine [15], the high incidences of polyploidy and mixoploidy are the result of polyspermy. It is likely that the polyploidy and mixoploidy noted in the present study were also the result of polyspermy.

In the present study, classification at the 2-day embryo stage showed that the incidence of chromosomal abnormalities differed among the various blastocyst groups; the blastocysts derived from 3- to 4-cell embryos and 5- to 8-cell embryos had fewer chromosomal abnormalities. In human cleaved embryos on day 3, however, Magli et al. [28] reported that the incidence of chromosomal abnormalities was significantly lower in 7-8-cell stage embryos than in slow-cleaving embryos (4-cell), moderately slowcleaving embryos (5-6-cell) and very fast-cleaving embryos ( $\geq 9$ cell). In regard to incidence of chromosomal abnormalities, it may be derived from the difference between porcine and human embryo development in vitro that the 3- to 4-cell and 5- to 8-cell stages produced good results for Day-2 porcine embryos produced by IVP, while the 7-8-cell stage produced good results for human IVF on day 3. Therefore, it could be that the speed of cleavage during early embryonic development is related to the incidence of chromosomal abnormalities. Furthermore, it may be concluded that the stage of embryo development and the embryonic morphology are related to the incidence of chromosomal abnormalities, since there was a significant difference in the incidence of chromosomal abnormalities among the expanded, expanding and early blastocysts. This relationship between the timing of development and the incidence of chromosomal abnormalities was not observed by Jakobsen et al. [37]; they found no significant differences among the chromosomal abnormalities of hatched, expanded and nonexpanded bovine blastocysts produced by IVP. Furthermore, in contrast to the results of the present study, they reported a high incidence of mixoploidy in all embryo groups, but they did not observe polyploidy or haploidy.

In the present study, the poor embryonic development of the blastocysts derived from the $>8$-cell embryos, which was manifested as a small number of cells and a high incidence of chromosomal abnormalities, may have been caused by the abnormal cleavage attributed to polyspermy as reported by Han et al. [36]. Furthermore, the small number of cells of blastocysts was related to the presence of polyploidy. This is in agreement with the report concerning pig embryos produced by IVP, which showed that the incidence of polyploidy decreased in embryos with many cells [15]. Mixoploidy may not be detrimental to blastocyst development in vitro because the mixoploid and normal diploid blastocysts contained many cells in the present study. Viuff et al. [40] reported that the frequency of mixoploidy in in vivo-derived embryos increases as the embryos develop from Day 2 to Day 5 after ovulation. Viuff et al. [41] reported that mixoploidy did not affect the developmental competence of embryos, since mixoploid embryos were generally observed on Day 5 in their fast-developing group of bovine embryos produced by IVP. In addition, in the present study, blastocysts derived from slow (2-cell embryos) and fast ( $>8$-cell embryos) cleaved Day-2 embryos displayed a significantly higher incidence of polyploidy than those derived from moderate cleaved embryos (3- to 4-cell embryos and 5- to 8-cell 
embryos); furthermore, normal embryonic development of the slow and fast cleaved embryos was adversely affected. Kawarsky et al. [42] found that bovine haploid and polyploid embryos produced by IVP develop slower than diploid and mixoploid embryos. In the present study, although it was not statistically significant due to an insufficient number of samples, the slow cleaved embryos had a higher incidence of haploidy than the moderate and fast cleaved embryos; this result might support the finding that mouse haploid parthenogenotes develop more slowly in culture during the preimplantation period than fertilization-derived diploid embryos [43].

In conclusion, the present study indicates that Day- 6 porcine blastocysts produced by IVP and derived from moderate cleaved stage Day-2 embryos (3- to 4-cell and 5- to 8-cell embryos) are superior in terms of quality, based on the ability of the embryo to develop, number of cells and incidence of chromosome abnormalities of the resultant blastocysts compared with slow (2-cell embryos) and fast ( $>8$-cell embryos) cleaved stage embryos on Day 2. Furthermore, among the blastocysts graded by stages of embryo development and morphology, expanded blastocysts had the highest quality based on the fact that they had the largest number of cells and the lowest incidence of chromosomal abnormalities.

The results of the present study can be used for selection of high quality embryos at the Day- 2 cleaved embryo and Day- 6 blastocyst stages of development.

\section{Acknowledgements}

We thank the management and staff of Utsunomiya Slaughterhouse in Tochigi Prefecture for their help in procuring porcine ovaries.

\section{References}

1. Betteridge KJ, Smith C, Stubbing RB, Xu KP, King WA. Potential genetic improvement in cattle by fertilization of fetal embryos in vitro. J Reprod Fert 1989; 38 (Suppl): 87-98.

2. Boerjan ML, den Dass JHG, Dieleman SJ. Embryonic origins of health: long term effects of IVF in human and livestock. Theriogenology 2000; 53: 537-547.

3. Day BN. Reproductive biotechnologies: Current status in porcine reproduction. Anim Reprod Sci 2000; 60-61: 161-172.

4. Betthauser J, Forsberg E, Augenstein M, Childs L, Eilertsen K, Enos J, Forsythe T, Goluke P, Jurgella G, Koppang R, Lesleister T, Mallon K, Mell G, Misica P, Pace M, Pfister-Genskow M, Strelchenko N, Voelker G, Watt S, Thompson S, Bishop M. Production of cloned pigs from in vitro systems. Nat Biotechnol 2000; 18: 1055-1059.

5. Nieman H, Rath D, Wrenzycki C. Advances in biotechnology: new tools in future pig production for agriculture and biomedicine. Reprod Domest Anim 2003; 38: 82-89.

6. Kashiwazaki N, Shino M. Ability of in vitro manipulated porcine embryos to develop to piglets. J Reprod Dev 2001; 47: 35-39.

7. Marchal R, Feaugang JM, Perreau C, Venturi E, Terqui M, Mermillod P. Meiotic and development competence of prepubertal and adult swine oocytes. Theriogenology 2001; 56: 17-29.

8. Kikuchi K, Onishi A, Kashiwasaki N, Iwamoto M, Noguchi J, Kaneko H, Akita T, Nagai T. Successful piglet production after transfer of blastocysts produced by a modified in vitro system. Biol Reprod 2002; 66: 1033-1041.

9. Wang WH, Abeydeera LR, Han YM, Prather RS and Day BN. Morphologic evaluation and actin filament distribution in porcine embryos produced in vitro and in vivo. Biol Reprod 1999; 60: 1020-1028.

10. Plachot M. Chromosome analysis of spontaneous abortions after IVF. A European survey. Hum Reprod 1989; 4: 425-429.

11. Causio F, Fischetto R, Sarcina E, Geusa S, Tartagni M. Chromosome analysis of spontaneous abortions after in vitro fertilization (IVF) and intracytoplasmic sperm injection (ICSI). Eu J Obst Gyn Rep Biol 2002; 105: 44-48.

12. Fraser LR, Zanellotti HM, Paton GR, Drury LM. Increased incidence of triploidy in embryos derived from mouse eggs fertilized in vitro. Nature 1976; 260: 39-40.

13. Yoshizawa M, Takada M, Nakamoto S, Muramatsu T, Okamoto A. Analysis of developmental ability of (BALB/c $\times$ C57BL/6) F1 and ICR mouse embryos fertilized in vitro and their chromosome at the first cleavage division. J Reprod Dev 1993; 39: 115122

14. Iwasaki S, Nakahara T. Incidences of embryos with chromosomal anomalies in the inner cell mass among bovine blastocysts fertilized in vitro. Theriogenology 1990; 34 683-690.

15. McCauley TC, Mozza MR, Didion BA, Mao J, Wu G, Coppola G, Coppola GF, Derardino DD, Day BN. Chromosomal abnormalities in day-6 in vitro-produced pig embryos. Theriogenology 2003; 60: 1569-1580.

16. Van der Hoeven FA, Cuijpers MP, De Boer P. Karyotypes of 3- or 4- day-old pig embryos after short in-vitro culture. J Reprod Fert 1985; 75: 593-597.

17. Viuff D, Rickords L, Offenberg H, Hyttel P, Avery B, Greve T. A high proportion of bovine embryos produced in vitro are mixoploid. Biol Reprod 1999; 60: 1273-1278.

18. Szczygiet $\mathbf{M}$, Kurpisz $\mathbf{M}$. Chromosomal anomalies in human gametes and preimplantation embryos, and their potential effect on reproduction. Andrologia 2001; 33: 249-265.

19. Linares T, King WA. Morphological study of the bovine blastocyst with phase contrast microscope. Theriogenology 1980; 14: 123-133.

20. Soom AV, Mateusen B, Leory J, de Kruif A. Assessment of mammalian embryo quality: What can we learn from embryo morphology? Reprod Biom 2003; 7: 664-670.

21. Gardner DK, Schoolcraft WB. In vitro culture of human blastocysts. In: Jansen R, Mortimer D (eds.), Towards Reproductive Certainty: Fertility and Genetics Beyond 1999 Carnforth: Parthenon Press, 1999: 378-388.

22. Veek LL. Oocyte assessment and biological performance. Ann NY Acad Sci 1988; 541 259-268.

23. Grisart B, Massip A, Dessy F. Cinematographic analysis of bovine embryo development in serum-free oviduct-conditioned medium. J Reprod Fert 1994; 101: 257-264.

24. Holm P, Shukri NN, Vajta G, Booth P, Bendixen C, Callesen H. Developmental kinetics of the first cell cycles of bovine in vitro produced embryos in relation to their in vitro viability and sex. Theriogenology 1998; 50: 1285-1299.

25. Lonergan P, Khatir H, Piumi F, Rieger D, Humblot P, Boland MP. Effect of time interval from insemination to first cleavage on the developmental characteristics, sex ratio and pregnancy rate after transfer of bovine embryos. J Reprod Fertil 1999; 117: 159-167.

26. McKiernan SH, Bavister BD. Timing of development is a critical parameter for predicting successful embryogenesis. Hum Reprod 1994; 9: 2123-2129.

27. Alikani M, Calderon G, Tomkin G, Garrisi J, Kokot M, Cohen J. Cleavage anomalies in early human embryos and survival after prolonged culture in vitro. Hum Reprod 2000; 15: 2634-2643

28. Magli MC, Gianaroli L, Ferraretti AP, Lappi M, Ruberti A, Farfalli V. Embryo morphology and development are dependent on the chromosomal complement. Fertil Steril 2007; 87: 534-541.

29. Suzuki K, Asano A, Eriksson B, Niwa K, Nagai T, Rodrigues-Martinez H. Capacitation status and in vitro fertility of boar spermatozoa; effects of seminal plasma, cumulus-oocyte- complexes-conditioned medium and hyaluronan. Int J Androl 2002; 25: 84 93.

30. Kikuchi K, Nagai T, Kashiwazaki N, Ikeda H, Noguchi J, Shimada A, Soloy E, Kaneko H. Cryopreservation and ensuing in vitro fertilization ability of boar spermatozoa from epididymides stored at $4^{\circ} \mathrm{C}$. Theriogenology 1998; 50: 615-623.

31. Petters RM, Wells KD. Culture of pig embryos. J Reprod Fert 1993; 48 (Suppl): 61-73.

32. Yoshizawa M, Matsukawa A, Matsumoto K, Suzuki K, Yasumatsu K, Zhu S, Muramatsu S. Required concentration and time of vinblastine treatment for chromosome preparation in bovine blastocyst derived from in vitro fertilization. J Reprod Dev 1998; 44: 59-64.

33. Somfai T, Kikuchi K, Onishi A, Iwamoto M, Fuchimoto D, Papp AB, Sato E, Nagai T. Meiotic arrest maintained by cAMP during the initiation of maturation enhances meiotic potential and developmental competence and reduces polyspermy of IVM/ IVF porcine oocytes. Zygote 2003; 11: 199-206.

34. Karja NWK, Medvedev S, Onishi A, Fuchimoto DI, Iwamoto M, Otoi T, Nagai T. Effect of replacement of pyruvate/lactate in culture medium with glucose on preimplantation development of porcine embryos in vitro. J Reprod Dev 2004; 50: 587-592.

35. Mateusen B, Soom AV, Maes DG, Donnay I, Duchateau L, Lequarre AS. Porcine embryo development and fragmentation and their relation to apoptotic markers: a cinematographic and confocal laser scanning microscopic study. Reproduction 2005. 129: 443-452

36. Han YM, Wang WH, Abeydeera LR, Petersen AL, Kim JH, Murphy C, Day, BN Prather RS. Pronuclear location before the first cell division determines ploidy of polyspermic pig embryos. Biol Reprod 1999; 61: 1340-1346.

37. Jakobsen AS, Preben DT, Birthe A. Few polyploidy blastomeres in morphologically superior bovine embryos produced in vitro. Theriogenology 2006; 65: 870-881. 
38. Farin PW, Crosier AE, Farin CE. Influence of in vitro systems on embryo survival and fetal development in cattle. Theriogenology 2001; 55: 151-170.

39. Yoshizawa M, Takada M, Nakamoto S, Muramatsu T, Okamoto A. Adequate concentration and duration of vinblastine treatment for chromosome preparation in mouse embryos. Jpn Anim Sci Technol 1991; 62: 511-518.

40. Viuff D, Hendriksen PJM, Vos PLAM, Dieleman SJ, Bibby BM, Greve T, Hyttel P, Thomsen PD. Chromosomal abnormalities and developmental kinetics in in vivodeveloped cattle embryos at days 2 to 5 after ovulation. Biol Reprod 2001; 65: 204-208.
41. Viuff D, Greve T, Avery T, Hyttel P, Brockhoff PB, Thomsen PD. Chromosomal aberrations in in vitro-produced bovine embryos at days $2-5$ post-insemination. Biol Reprod 2000; 63: 1143-1148.

42. Kawarsky SJ, Basrur PK, Stubbings RB, Hansen PJ, King WA. Chromosomal abnormalities in bovine embryos and their influence on development. Biol Reprod 1996; 54 53-59.

43. Henery CC, Kaufman MH. Cleavage rate of haploid and diploid parthenogenetic mouse embryos during the preimplantation period. Mol Reprod Dev 1992; 31: 258-292. 